\title{
Improving the Quality and Durability of Restorative Coatings by Arc Deposition and Modification with Natural Additive Bentonite Clay
}

\author{
Tamara Skoblo, Ivan Rybalko*, Aleksandr Saychuk, Aleksandr Tihonov \\ Kharkiv Petro Vasylenko National Technical University of Agriculture, Ukraine, \\ *corresponding author: irybalko.ua@gmail.com
}

\begin{abstract}
The study considers the possibility of improving the quality and service life of reducing coatings by arc deposition and modifying with natural additive bentonite clay. It has been established that when the modifier is introduced into the fluid bath during arc deposition, the phases and their interactions change. Introduction of the modifying additive bentonite clay significantly changes the crystalline lattice of the carbide phases. The optical-mathematical method revealed the absence of austenite and the pair interaction of ferrite-carbide during modification. The maximum proportion of phases corresponds to ferrite $(33.8 \%$ - 2 times decrease) and ferrite-austenite-carbide interaction $(48.62 \%-2$ times increase). The ferrite-austenite interaction increases almost 8 times during modification. The wear coefficient in this case is 2.2 times lower in comparison with the original steel $65 \mathrm{G}$ and 1.4 times lower in relation to arc deposition with only T-620 electrode.
\end{abstract}

Key words: bentonite clay, optical-mathematical method modification, arc deposition, microhardness, coercive force.

\section{INTRODUCTION}

Popular edge tools (ploughshare, chisels, cultivator tines, knives, blades, cutters, etc.), are used in soil cultivating operations provide efficiency of machinery used in agriculture. It is known that creating two-layer edge tools as a rule surface-hardened with hard-alloy coatings is an effective way to improve their wear resistance and soil tillage quality [1][2][3][[4]. When soil properties are changed, the conditions of the relative wear resistance of the same products can be changed significantly [5][6][7]. This, accordingly, affects the characteristics of the efficiency of new hardened products usage. The generalized dependence of wear relation with the level of acting specific pressures is considered in study [8]. The coefficients of relative wear resistance of different hardening materials used in coatings are achieved more closely with the increase in the hardness of the cultivated soil.
For local hardening of the part surface in the wear areas it is advisable to use various methods of hardening, namely, arc deposition with piece electrodes or flux-cored wires [9], flux-cored materials on induction installations, as well as plasma [10] and gas-flame powders, wire [11][12].

Arc deposition with stick electrodes or wires can be as solid coating over the entire surface, and locally (varying degrees of locality). Studies [13][14][15] found that such arc deposition proved to be better in operating conditions, with an insignificant increase in soil resistance. Such hardening sufficiently protects the base layer of the cutting tool metal from wear.

The method of increasing the service life of cultivator tines due to the combined three-layer formation of their working surfaces has been revealed, namely: 1 - base - steel 65G; 2 hardened layer of steel $65 \mathrm{G}$ to the depth of 1,9-2,3 mm using electric contact method of hardening [13], and the total hard layer is $3,48 \mathrm{~mm}$ relatively to the original steel $65 \mathrm{G} ; 3$ additional hardening is performed by a special electrode $\mathrm{T}-590 \varnothing 5 \times 450 \mathrm{~mm}$ and its wear resistance is $4,49 \mathrm{~mm}$ relatively to the original steel $65 \mathrm{G}$ [16].

The method of restoration of parts subjected to increased wear with arc deposition was considered in study [17]. It was applied under a layer of flux obtained from ash wastes of power generation after special processing. It is low-cost and provides improvement of the required properties because it includes alloying and modifying additives $(\mathrm{V}, \mathrm{Ti}, \mathrm{Cu}, \mathrm{Mn}, \mathrm{Al}$, $\mathrm{Si}$ ). However, such modification technology is used for more massive parts than the tools of agricultural machines cultivator tines with a thickness of 5.5-6 mm. This is due to the fact that the use of such additional alloying requires increasing and ensuring stable temperature of the fluid bath. Restoring a part by this method will result in melting of the cultivator share.

It is also known to use a modifying additive to improve the quality and wear resistance by surfacing strips on the cultivator tines to improve its properties and operational durability [18]. For this purpose, during arc deposition secondary raw materials are used such as detonation charge from the disposal of ammunition, which has expired storage 
period. This modifying charge provides reduction of the temperature of the liquid bath during surfacing due to the fact that it contains a diamond fraction in the form of nano- and dispersed inclusions, which are not dissolved and are microcoolers. They reduce the heat-affected zone and transition zone (up to 50\%) and are preserved in the metal during surfacing and are characterized by a lower exertion level.

The disadvantage of using such a charge is that companies don't have the ability to consistently obtain such secondary raw materials for modification, as well as the lack of devices to control its composition.

The cheapest and most accessible coating can be a natural product for modification - bentonite clay. There is a known U.S. patent [19], according to which for the increasing of wear resistance, such clay is introduced into the mating, which forms a ceramic coating on the surface under friction. It was decided to use the clay for modification during surfacing based on these studies.

The purpose of the research was to investigate the possibility of using natural raw materials - bentonite clay - to modify the clad metal coating.

\section{MATERIALS AND EXPERIMENTAL METHODS}

The most effective modifying additive is bentonite clay with a fine-grained powder fraction. Its influence on changing the structural state of the surface of cultivator tines during surfacing can contribute to an increase in wear resistance, especially considering the fact that the components and their compounds in it are in the soil with which these products work and they are close in composition. When selecting such a natural substance for the modification, it was assumed that its admixture is available for usage and it includes increased $\mathrm{Si}$ and $\mathrm{Al}$ content and these components are partially in compounds with oxygen $\left(\mathrm{SiO}_{2}\right.$ and $\left.\mathrm{Al}_{2} \mathrm{O}_{3}\right)$. In the particular case under consideration, the chemical composition of bentonite clay has, in percentage correlation: $1.65 \mathrm{Fe} ; 0.25 \mathrm{~K}$; $0.15 \mathrm{Ca} ; 0.06 \mathrm{~S} ; 0.2 \mathrm{Mn} ; 54.88 \mathrm{Si} ; 32.42 \mathrm{Al} ; 0.3 \mathrm{Na} ; 0.2 \mathrm{Mg}$.

Considering the fact that the most effective modifying additive of such admixture, which is $5-7 \%$ of the electrode share, it will be as follows, in percentage correlation: $0,10 \mathrm{Fe}$; $0,02 \mathrm{~K} ; 0,01 \mathrm{Ca} ; 0,004 \mathrm{~S} ; 0,012 \mathrm{Mn} ; 3,3 \mathrm{Si} ; 1,95 \mathrm{Al}$. With a decrease in the share of its addition in the coating, the effect of modification is significantly reduced, because the carbide phase in the arc deposition is not evenly crushed, as well as the grain size changes only in local areas. The increase in the share of admixture (> 10-12\%) leads to the appearance and growth of complex nonmetallic inclusions, which reduces the quality of the coating. In this case, micro-hardness inhomogeneity also occurs.
To decide the efficiency of this modification, the structure of the deposited coating was studied using a JSM-6390 LV scanning electron microscope with an INCA Energy 350 $\mathrm{X}$-ray analysis system to obtain the thermos-electron emission of individual inclusions and their distribution in the coating. The micro-hardness was evaluated with a UIT-HVmicro1 hardness tester model.

The obtained images were analyzed using previously developed approaches [20][21]. Each image of a structure in the digital .bmp format was divided into fragments of $3 \times 3$ pixels and their variability was analyzed depending on the location. In each flow of the metallographic image with coordinates $(x, y)$, a conditional color was determined, given by the value of the Laplacian function (1), by means of which energy dissipation was described [22]:

$$
L(x, y) \equiv \Delta C(x, y)=\frac{\partial^{2} C(x, y)}{\partial x^{2}}+\frac{\partial^{2} C(x, y)}{\partial y^{2}}
$$

In the finite-difference representation, the function $C(x, y)$ had the form of the matrix $C_{i, j}$ of size $3 \times 3$ pixels:

$$
C_{i, j}=\left(\begin{array}{ccc}
c_{i-1, j-1} & c_{i-1, j} & c_{i-1, j+1} \\
c_{i, j-1} & c_{i, j} & c_{i, j+1} \\
c_{i+1, j-1} & c_{i+1, j} & c_{i+1, j+1}
\end{array}\right)
$$

This matrix was processed by sequential scanning and each pixel was evaluated by setting it with a color point inside a fragment of a given size. A pixel of the image (with a central value $C_{i, j}$, where $I$ and $j$ are the row and column numbers, respectively) was chosen as coordinates. The finite-difference representation of diffusion processes was estimated using the Laplacian (3) for each point of the analyzed image fragment, which had the form:

$$
\begin{aligned}
& L(x, y) \approx \frac{\Delta^{2} c}{\Delta x^{2}}+\frac{\Delta^{2} c}{\Delta y^{2}}= \\
& =L_{i j}=c_{i, j-1}+c_{i-1, j}+c_{i, j+1}+c_{i+1, j}-4 c_{i, j}
\end{aligned}
$$

where a coordinate step on the digital image $\Delta \mathrm{x}=\Delta \mathrm{u}=1$. The variability estimated in a particular point of the selected image fragment was given by the ratio of the number of coincidences of the conditional color of the middle point relative to the points around it.

\section{RESULTS AND DISCUSSION}

Arc deposition coatings in both cases form a martensite structure [23] (Figure 1). Figure 2 shows the composition of inclusions in which an increased content of $\mathrm{Cr}, \mathrm{Mn}, \mathrm{Si}$ and oxygen was detected. Individual components and inclusions 
of $\mathrm{C}, \mathrm{Al}_{2} \mathrm{O}_{3}$, Ca were detected in them. This distribution of components was also evaluated by thermos-electron emission method.

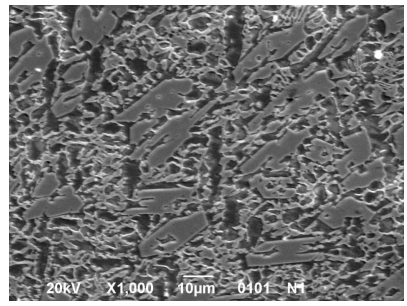

a

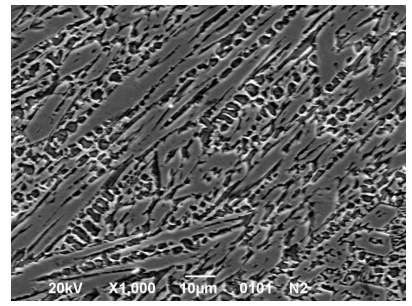

b
Figure 1: The formed structure during arc deposition: a - with electrode; $b$ - with additional modification with clay

To use this modifying additive it was dried at $\mathrm{t}=240^{\circ} \mathrm{C}$ and then milled in a ball mill to a grain size of 40-50 microns for 2 hours. After that, glue was added to the powder, stirred and applied to the electrode, dried at $\mathrm{t}=180^{\circ} \mathrm{C}$, and then used to form the coating by arc deposition. It is established that such technological process of modification provides the change in structure formation. The carbide phase is crushed, it is distributed more evenly and its share increases by $30 \%$, the transition zone and thermal influence decrease by 40 and $30 \%$ respectively, and the degree of penetration of thin-walled cultivator tines decreases and is only $60 \%$, while without modification with clay its damageability is noted.

Microhardness also changes slightly due to such modification (Figure 3). It was established that irrespective of measurements direction - crosswise or longitudinal (was estimated on diagonals of prints) at optimal modification microhardness is more uniform and changes in coating from H-50-671,6 (matrix) and to H-50-1193,9 (carbides), and without modification from $\mathrm{H}-50-686,1$ to $\mathrm{H}-50-1283,3$ respectively. The high level of microhardness in an initial condition of a covering (without modification) corresponds to a transition zone and is connected with that contains the most part of rough inclusions of a carbide phase in this variant and defines change of indicators, and also depends on exertion level. The total share of the crushed carbide inclusions increases with clay modification (Figure 4). Their share increases by $20 \%$ due to decrease of fluid bath temperature during coating with modifying additive. We analyzed the composition in the hardened, reduced layer and evaluated the local distribution of components included in the modifying additive and T-620 electrode (chemical composition, in percentage correlation: $3.0 \mathrm{C} ; 2.2 \mathrm{Si} ; 1.2 \mathrm{Mn} ; 22.5 \mathrm{Cr}$; $0.7 \mathrm{Ti}$; $0.8 \mathrm{~B} ; 0.03 \mathrm{~S})$.

It is found (Figure 5) that carbon, $\mathrm{Ti}, \mathrm{Ca}, \mathrm{Al}$ are distributed quite evenly, $\mathrm{Cr}$ is detected only in the structurally free carbide phases, and Mo, Mn in the matrix phase. The largest share of $\mathrm{Si}$ is concentrated in the matrix phase, and this component is also distributed in the more massive inclusions of chromium carbides (divides them into separate fragments and they become thinner). Iron is not detected in chromium carbides, so they can be attributed to inclusions $\mathrm{Cr}_{7} \mathrm{C}_{3}$ (eutectic), and matrix to $\mathrm{Cr}_{23} \mathrm{C}_{6}$. The distribution of oxygen is heterogeneous, but, as shown by local spectral microanalysis, its share does not exceed $15.98 \%$.

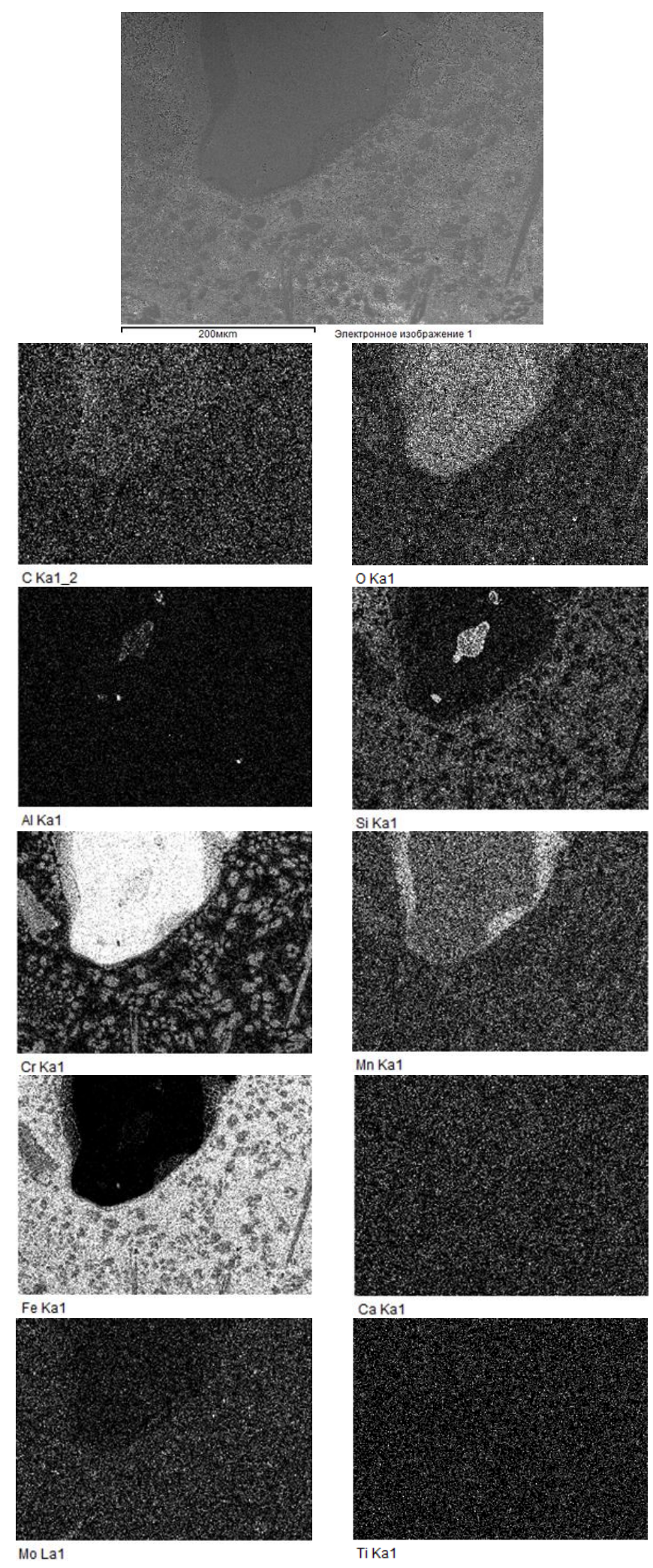

Figure 2: Composition of inclusions when clay is added to the arc deposition. Thermo-electronic emission 


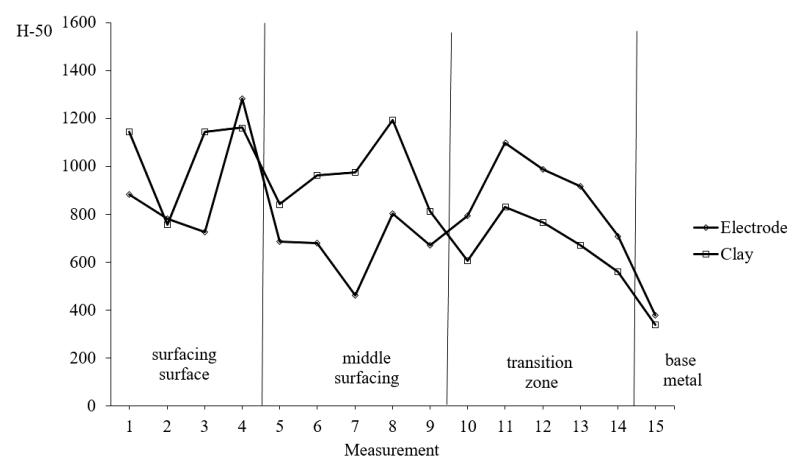

Figure 3: Change of microhardness according to the depth of coating: a - with electrode T-620; b - with additional input of bentonite clay

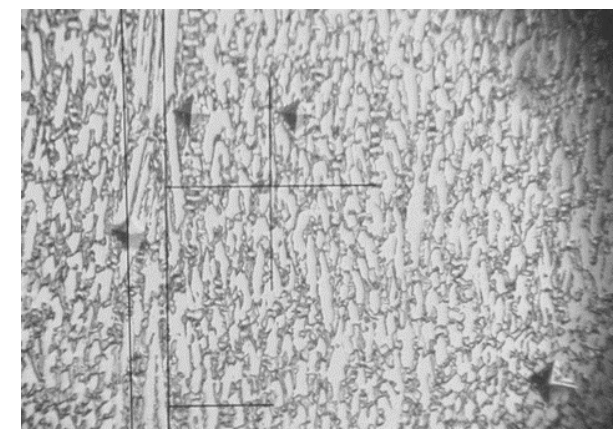

Figure 4: Arc deposition structure modified with clay, x200

It was also necessary to establish the strength of the connection between the coating and the base metal in order to use such a modifying additive. The evaluation was carried out using the microhardness measurement method, where it was shown that a load of even up to $1 \mathrm{~kg}$ on the indenter did not contribute to the damage of the connection. This can be explained by the fact that during modification the stresses in the boundary transition layer of the coating also decrease. Table 1 shows the results of bench wear tests, which show that the wear coefficient is 2.2 times lower in comparison with the original steel $65 \mathrm{G}$ and 1.4 times lower in relation to arc deposition with only electrode T-620.

The formed microstructures were analyzed comparatively using the optical-mathematical method, which were described in the digital format .bmp. The variability of color tints from 0 to 255 was distinguished. The phases were divided into four groups with 16 intervals (conventional colors). The conventional colors were taken as follows: 01-09 - ferrite, 10 - bainite, 11-16 - carbides (Table 2).

It follows from the data obtained that additional modification of the fluid bath with clay shows differences in crystallization of the share of ferrite phases, the share of bainite component increases as well as carbides of non-stoichiometric composition №12-14.
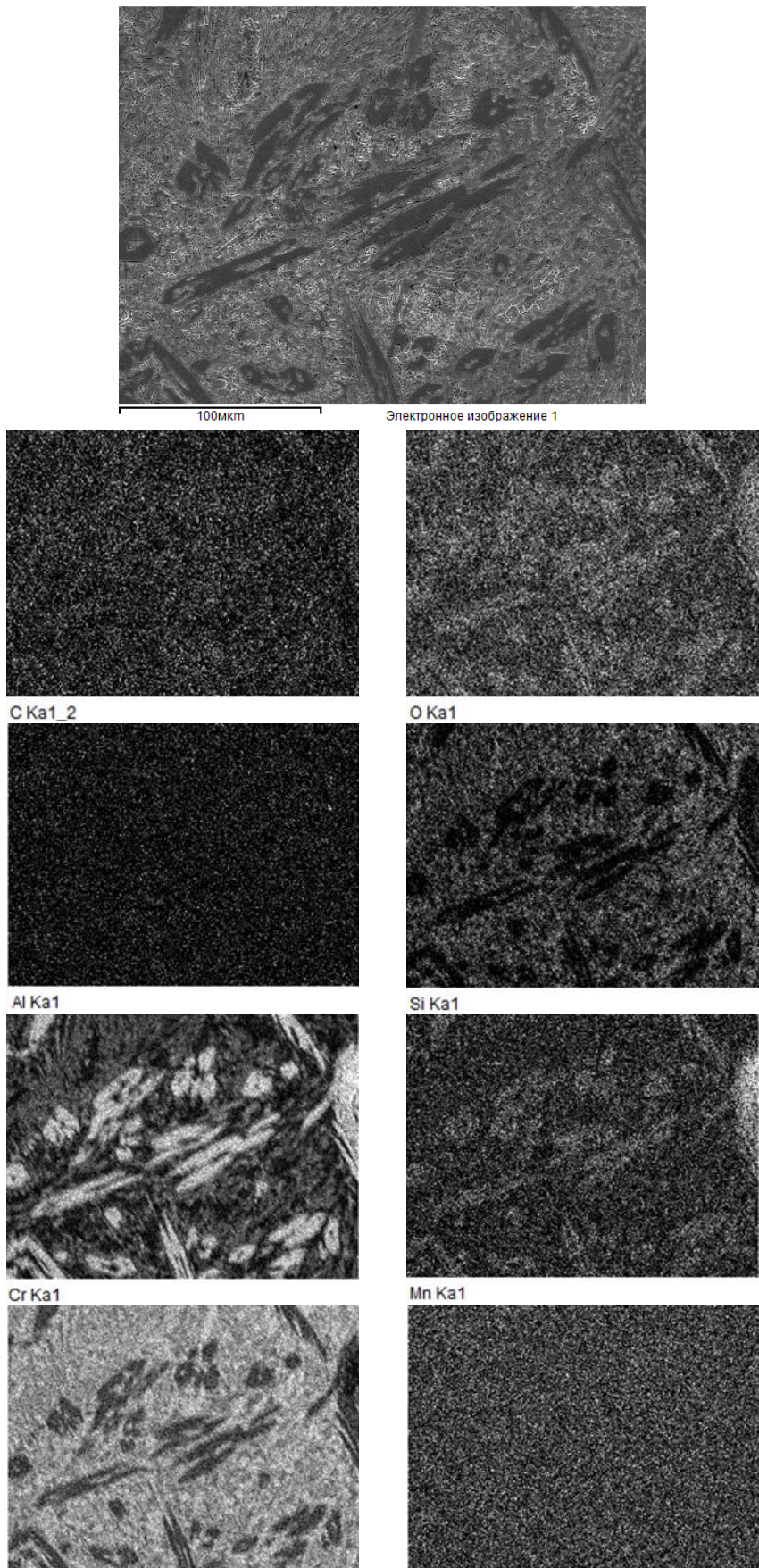

Mn Ka1
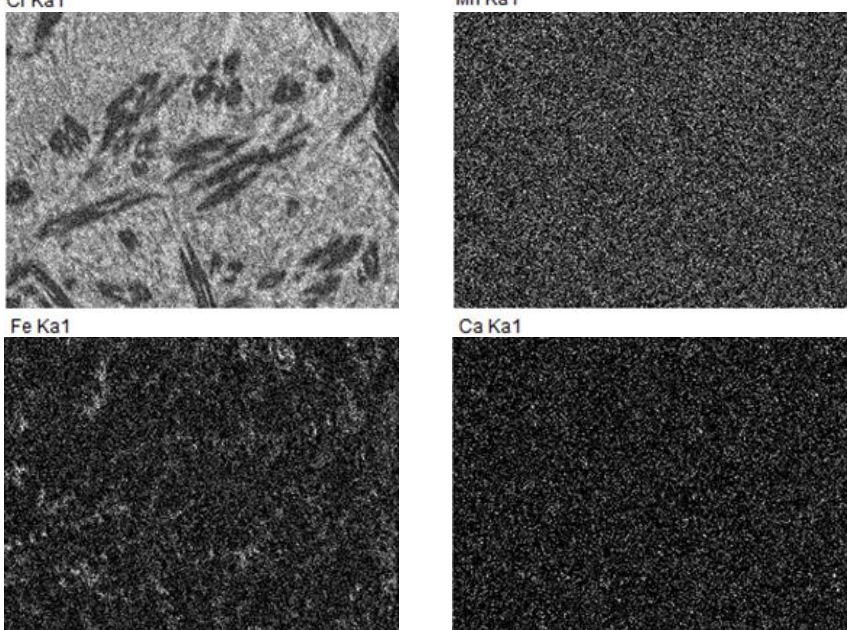

MoLa1

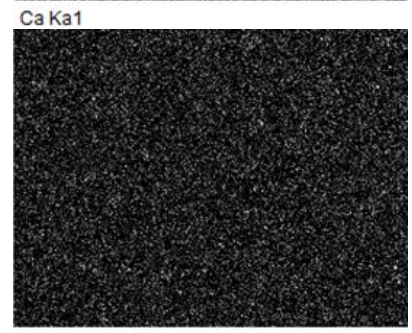

TiKa1

Figure 5: Distribution of components in the coating modified with bentonite clay 
Tamara Skoblo et al., International Journal of Emerging Trends in Engineering Research, 9(6), June 2021, 643 - 650

Table 1: Wear resistance test under abrasive conditions

\begin{tabular}{|c|l|c|}
\hline $\begin{array}{c}\text { No } \\
\text { n/a }\end{array}$ & \multicolumn{1}{|c|}{ Strengthening option } & $\begin{array}{c}\text { Wear } \\
\text { rate }\end{array}$ \\
\hline 1 & Initial material cultivator tines steel 65G & 1.0 \\
\hline 2 & Arc deposition with T-620 electrode & 0.62 \\
\hline 3 & $\begin{array}{l}\text { Arc deposition with T-620 electrode with } \\
\text { additional modification of bentonitic clay } \\
(5-7 \%)\end{array}$ & 0.45 \\
\hline
\end{tabular}

Table 2: Number of colors corresponding to 16 intervals, in percentage correlation

\begin{tabular}{|c|c|c|c|c|c|c|c|c|}
\hline & $\mathbf{1}$ & $\mathbf{2}$ & $\mathbf{3}$ & $\mathbf{4}$ & $\mathbf{5}$ & $\mathbf{6}$ & $\mathbf{7}$ & $\mathbf{8}$ \\
\hline Fig. 1a & 12. & 17. & 10. & 10. & 10. & 10. & 09. & 08. \\
& 7 & 9 & 2 & 5 & 0 & 3 & 7 & 6 \\
\hline Fig. 1b & 17. & 08. & 11. & 06. & 06. & 11. & 08. & 06. \\
& 5 & 1 & 6 & 3 & 1 & 4 & 8 & 6 \\
\hline & $\mathbf{9}$ & $\mathbf{1 0}$ & $\mathbf{1 1}$ & $\mathbf{1 2}$ & $\mathbf{1 3}$ & $\mathbf{1 4}$ & $\mathbf{1 5}$ & $\mathbf{1 6}$ \\
\hline Fig. 1a & 01. & 01. & 04. & 00. & 01. & 00. & 00. & 00. \\
& 7 & 4 & 3 & 7 & 4 & 4 & 1 & 0 \\
\hline Fig. 1b & 07. & 06. & 03. & 02. & 02. & 01. & 00. & 00. \\
& 6 & 0 & 0 & 8 & 0 & 4 & 7 & 1 \\
\hline
\end{tabular}

Average neutrality was also revealed from the images (see Figure 1). Various methodological approaches were used to evaluate the Laplacians and divergence, average structure homogeneity, and various functions (Tables 3 and 4), which can most fully characterize the features in the structure formation of the different coating options that were compared during arc deposition without modification. This evaluation methodology is described in detail in [20][21][24][25][26].

Table 3: Generalized structure of the whole image (without grouping into 16 intervals)

Average neutrality

\begin{tabular}{|c|c|c|c|c|c|}
\hline 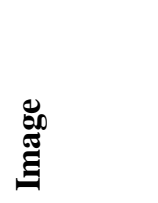 & 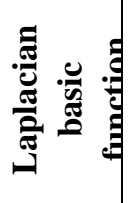 & 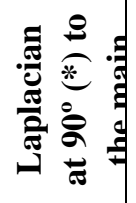 & లై & 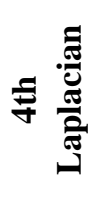 & 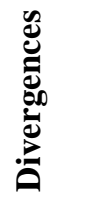 \\
\hline Figure $1 \mathrm{a}$ & 0.784 & 0.777 & 0.644 & 0.610 & 0.872 \\
\hline Figure $1 \mathrm{~b}$ & 0.768 & 0.760 & 0.628 & 0.597 & 0.855 \\
\hline
\end{tabular}

(*) Note: the Laplacian at an angle of $90^{\circ}$ characterizes relatively to its main function - anisotropy.

Average homogeneity

\begin{tabular}{|c|c|c|}
\hline \multicolumn{3}{|c|}{ Average homogeneity } \\
\hline Image & By rows & By columns \\
\hline Figure 1 a & 0.649 & 0.633 \\
\hline Figure 1 b & 0.670 & 0.651 \\
\hline \multicolumn{3}{|c|}{ Average functions 1} \\
\hline
\end{tabular}

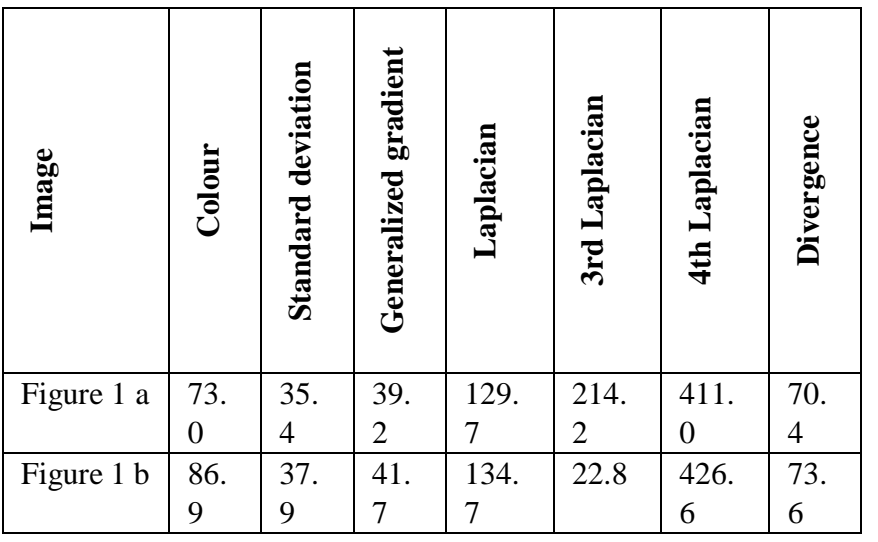

Continuation of table 3 Average functions 2 with values more than 255

\begin{tabular}{|c|c|c|c|c|}
\hline Image & Divergence & Laplacian & $\begin{array}{c}\text { 3rd } \\
\text { Laplacian }\end{array}$ & $\begin{array}{c}\text { 4th } \\
\text { Laplacian }\end{array}$ \\
\hline Figure1 a & 82.5 & 138.8 & 224.8 & 420.9 \\
\hline Figure1 b & 86.9 & 145.0 & 234.2 & 437.2 \\
\hline
\end{tabular}

Average functions 3 - average color relations

\begin{tabular}{|c|c|c|c|c|c|}
\hline 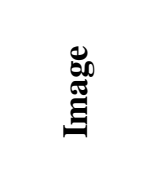 & مَّ & 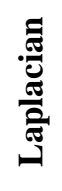 & ๗ & 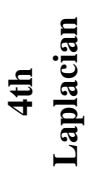 & 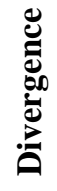 \\
\hline Figure $1 \mathrm{a}$ & 1.4 & 5.2 & 8.2 & 16.0 & 2.7 \\
\hline Figure $1 \mathrm{~b}$ & 1.3 & 4.5 & 7.0 & 13.5 & 2.4 \\
\hline
\end{tabular}

The given calculations in Tables 3 and 4 make it clear that the analyzed parameters do not contribute significantly to the structure formation with additional clay modification. Then, the content of phases and their interaction were analyzed (Table 5).

Table 4: Generalized structure formation of the whole image (grouped into 16 intervals)

\begin{tabular}{|c|c|c|c|c|c|}
\hline \multicolumn{6}{|c|}{ Average neutrality } \\
\hline 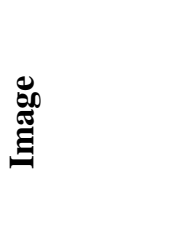 & 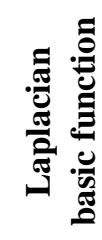 & 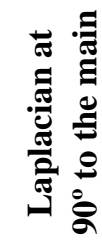 & 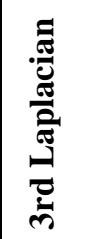 & 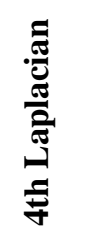 & 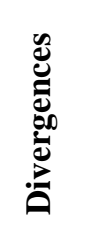 \\
\hline Figure $1 \mathrm{a}$ & 0.792 & 0.788 & 0.659 & 0.627 & 0.816 \\
\hline Figure $1 \mathrm{~b}$ & 0.774 & 0.768 & 0.641 & 0.614 & 0.795 \\
\hline \multicolumn{6}{|c|}{ Average homogeneity } \\
\hline \multicolumn{2}{|c|}{ Image } & \multicolumn{2}{|c|}{ By rows } & \multicolumn{2}{|c|}{ By columns } \\
\hline \multicolumn{2}{|c|}{ Figure $1 \mathrm{a}$} & \multicolumn{2}{|c|}{0.782} & \multicolumn{2}{|c|}{0.771} \\
\hline \multicolumn{2}{|c|}{ Figure $1 \mathrm{~b}$} & \multicolumn{2}{|c|}{0.802} & \multicolumn{2}{|c|}{0.790} \\
\hline
\end{tabular}




\begin{tabular}{|c|c|c|c|c|c|c|c|}
\hline $\begin{array}{l}\stackrel{\Xi}{0} \\
\text { E્ }\end{array}$ & $\frac{\Xi}{\partial}$ & 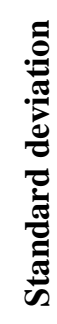 & 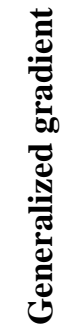 & 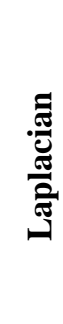 & 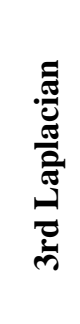 & 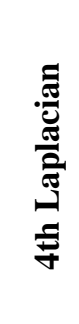 & 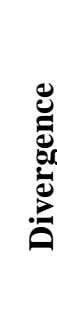 \\
\hline Figure 1 a & 4.8 & 2.1 & 2.3 & 7.8 & 12.8 & 24.6 & 4.2 \\
\hline Figure $1 \mathrm{~b}$ & 5.6 & 2.2 & 2.4 & 7.8 & 12.9 & 24.8 & 4.3 \\
\hline
\end{tabular}

Average functions 2 with values more than 255

\begin{tabular}{|c|c|c|c|c|}
\hline Image & $\begin{array}{c}\text { Divergenc } \\
\mathbf{e}\end{array}$ & Laplacian & 3rd Laplacian & 4th Laplacian \\
\hline Figure 1 a & 16.6 & 18.5 & 23.7 & 35.1 \\
\hline Figure 1 b & 16.2 & 19.5 & 24.7 & 36.0 \\
\hline
\end{tabular}

Continuation of table 4

Average functions 3 - average color relations

\begin{tabular}{|c|c|c|c|c|c|}
\hline 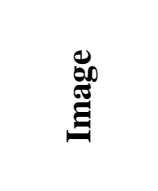 & مإ் & & లై & 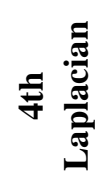 & 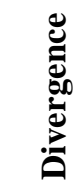 \\
\hline Figure $1 \mathrm{a}$ & 0.5 & 1.8 & 3.0 & 5.6 & 1.0 \\
\hline Figure $1 \mathrm{~b}$ & 0.5 & 1.6 & 2.6 & 5.0 & 0.9 \\
\hline
\end{tabular}

Table 5: Percentage of phases in cells 3 by 3 (image Figure 6)

\begin{tabular}{|l|l|ll|}
\hline \multicolumn{1}{|c|}{$\begin{array}{c}\text { First image } \\
\text { (Figure 1 a) }\end{array}$} & \multicolumn{1}{|c|}{$\begin{array}{c}\text { Second image } \\
\text { (Figure 1 b) }\end{array}$} & \multicolumn{1}{|c|}{$\begin{array}{c}\text { Phases and } \\
\text { their } \\
\text { interaction }\end{array}$} \\
\hline 71.2756776691868 & 33.8004794394247 & Ferrite \\
\hline 0 & 0 & Austenite \\
\hline $\begin{array}{l}0,60040567951318 \\
5\end{array}$ & 1.75622349253181 & Carbides & \\
\hline 2.31901161718606 & 15.6946339664392 & $\begin{array}{l}\text { Ferrite } \\
\text { austenite }\end{array}$ \\
\hline 0.89028213166144 & 0.12391665130001 & $\begin{array}{l}\text { Austenite } \\
\text { carbides }\end{array}$ \\
\hline 2 & 8 & $\begin{array}{l}\text { Ferrite } \\
\text { carbides }\end{array}$ \\
\hline 7.37599114881062 & 0 & $\begin{array}{l}\text { Ferrite } \\
\text { austenite } \\
\text { carbides }\end{array}$ \\
\hline 24.9138853033376 & 48.6247464503043 & - \\
& & & \\
\hline
\end{tabular}

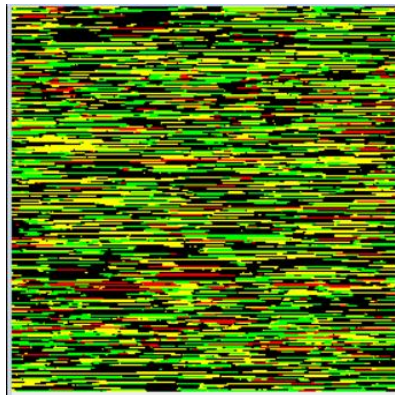

a

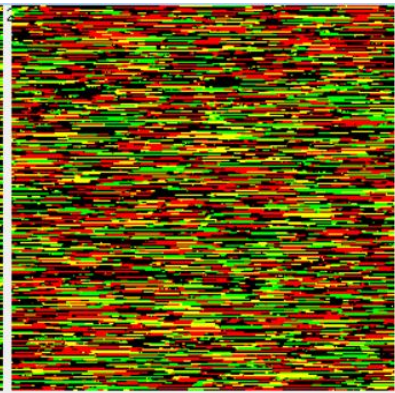

$\mathrm{b}$
Figure 6: Formed phases during arc deposition: a - with electrode; $\mathrm{b}$ - with additional input of bentonite clay

Processing the results of this table by scanning a $3 \times 3$ pixel cell revealed only two separate ferrite and carbide phases. There is no austenite and pairwise ferrite-carbide interaction in the modification. The maximum proportion of phases corresponds to ferrite $(33.8 \%)$ with different carbon content and ferrite-austenite-carbide interaction $(48.62 \%)$. When the clay is modified, the ferrite-austenite interaction increases almost 8 times. The fraction of ferrite phases decreases twice, but the interaction ferrite-austenite-carbides increases twice.

The color combinations are close to each other. At the same time, the percentages of phases are different. This indicates that next to the 3 by 3 cell, there is another cell with a different phase, and there are quite a few such different pairs.

In this paper, the colors are indicated (see Figure 6): black ferrite is phase number 1 for all 9 points of the 3 by 3 pixels cell; the second phase - austenite for all 9 points is absent; blue is the third phase carbide in all nine points; green is phase number 4 - ferrite-austenite; yellow is phase number 5 austenite-carbide.

The ferrite-carbide phase connection number 6 is missing in both image; red is the ferrite-austenite-carbide phase interaction number 7 .

Based on the data in Table 5, we can assume that the introduction of the modifying additive bentonite clay will significantly change the crystalline lattice of the carbide phases. In a number of cases, metallographic studies revealed separation of coarse needle-like carbides of non-stoichiometric composition into thinner ones formed during crystallization, as well as their more intensive crushing. The proportion of such carbides increases 2 times during modification. Bentonite clay creates a complex crystalline structure.

The effect of introducing bentonite clay into the arc deposition on the change in the stress-strain state according to the coercive force was analyzed [27]. For this purpose, measurements were carried out on a new cultivator share and 
Tamara Skoblo et al., International Journal of Emerging Trends in Engineering Research, 9(6), June 2021, 643 - 650

after arc deposition the rolls hardening the working surface according to the previously proposed scheme [18]. Analyzing the data obtained (Table 6), the following is observed: arc deposition reduces the level of coercive force by $26-42 \%$, as well as the ratio of phases and their tines (see Table 5).

Table 6: Changes of the coercive force on the compared Tiger Mate II tines before and after hardening

\begin{tabular}{|c|c|c|c|c|c|c|c|c|c|}
\hline \multirow{2}{*}{ Sample } & \multicolumn{7}{|c|}{ Measurement reference number } \\
\cline { 2 - 10 } & 1 & 2 & 3 & 4 & 5 & 6 & 7 & 8 & 9 \\
\hline $\begin{array}{l}\text { New tine } \\
\text { top (tip) }\end{array}$ & 20.1 & 19,2 & 18.7 & 18.06 & 17.7 & 17.9 & 17.9 & 13.3 & 18.0 \\
\hline $\begin{array}{l}\text { After } \\
\text { hardening } \\
\text { top (tip) }\end{array}$ & 20.2 & 19,7 & 22.0 & 12.2 & 13.1 & 12.7 & 11.8 & 9.3 & 12.1 \\
\hline $\begin{array}{l}\text { After } \\
\text { hardening } \\
\text { bottom } \\
\text { fenders) }\end{array}$ & 20.0 & 20.5 & 20.9 & 14.9 & 14,0 & 12.5 & 11.8 & 12.7 & 10.6 \\
\hline \begin{tabular}{l} 
Sample \\
\cline { 2 - 11 }
\end{tabular} & 10 & 11 & 12 & 13 & 14 & 15 & 16 & 17 & 18 \\
\hline $\begin{array}{l}\text { New tine } \\
\text { top (tip) }\end{array}$ & 17.8 & 18.4 & 19.06 & 19.5 & 20.1 & 20.9 & 13.7 & 14.4 & 18.1 \\
\hline $\begin{array}{l}\text { After } \\
\text { hardening } \\
\text { top (tip) }\end{array}$ & 15.3 & 11.0 & 11.1 & 20.7 & 19.6 & 20.8 & 11.6 & 16,0 & 15.7 \\
\hline $\begin{array}{l}\text { After } \\
\text { hardening } \\
\text { bottom } \\
\text { fenders) }\end{array}$ & 12.1 & 12.3 & 13.0 & 20.0 & 19.7 & 18.6 & 12.3 & 18.9 & 20.0 \\
\hline
\end{tabular}

This can significantly change the process of wear and deformation of cultivator tines. The technical field tests carried out under production conditions showed an increase in wear resistance of the modified coatings by 2.2 times. At this stage of the research, testing of the coating technology in the field has started and there are already positive results.

\section{CONCLUSION}

Based on the obtained results of modifying the restorative coating with a natural component - bentonite clay, it is characterized by increased properties, which allows to significantly reduce the costs of using modifiers in production. Such a charge is available for usage by small enterprises when restoring parts, especially those who work with soil.

The proposed technological process of modification provides a change and structure formation, the carbide phase is crushed and distributed more evenly and its proportion increases by $30 \%$, the transition zone and thermal influence decreases by 40 and $30 \%$ respectively, and the degree of penetration of thin-walled cultivator tine decreases and is only $60 \%$.

At optimum modification with $5-7 \%$ bentonite clay microhardness is more homogeneous and varies in coating from H-50-671,6 (matrix) and up to H-50-1193,9 (carbides). Technical field tests determined that the wear coefficient is 2.2 times lower compared to the original steel $65 \mathrm{G}$ and 1.4 times lower in relation to arc deposition only with electrode T-620.

The description by the optical-mathematical method revealed the absence of austenite and the pairwise ferrite-carbide interaction during modification. The maximum fraction of phases corresponds to ferrite $(33.8 \%$ - 2 times decrease) and ferrite-austenite-carbide interaction $(48.62 \%-2$ times increase); the ferrite-austenite interaction increases almost 8 -fold with modification.

Introduction of the modifying additive bentonite clay significantly changes the crystalline lattice of carbide phases. Metallographic studies revealed the separation of lancets of non-stoichiometric carbides into thinner ones formed during crystallization, as well as their more intensive crushing. The fraction of such carbides during modification increases by 2 times.

It was found that arc deposition with additional modification of the fluid bath with bentonite clay reduces the level of coercive force by $26-42 \%$.

\section{REFERENCES}

1. D.B. Bernshtejn. Abrazivnoe iznashivanie lemeshnogo lezviya i rabotosposobnost' pluga, Traktory $i$ sel'khozmashiny, № 6. c. 39-42, 2002

2. S.A. Sidorov, D.A. Mironov, V.K. Khoroshenkov, and E.I. Khlusova. Surfacing Methods for Increasing the Service Life of Rapidly Wearing Working Tools of Agricultural Machines, Welding International, Vol. 30, Issue 10, pp. 808-812, 2016. DOI 10.1080/09507116.2016.1148408

3. V.S. Surilov, and V.A. Ovchinnikov. Issledovanie iznosostojkosti dvukhslojnykh i odnorodnykh diskov lushchil'nikov, Traktory i sel'khozmashiny, № 8, pp. 28-29, 1970.

4. V.N. Tkachev, and I.L. Kogan. Povyshenie dolgovechnosti diskovykh rabochikh organov pochvoobrabatyvayushchikh mashin, Traktory $i$ sel'khozmashiny, № 8, C. 32-33, 1969.

5. V.G. Kolesov. O povyshenii dolgovechnosti detalej, iznashivayushchikhsya pri trenii o grunt, i racional'nom vybore splavov dlya ikh naplavki, Vestnik mashinostroeniya, № 9, C. 22-26, 1961.

6. A.Sh. Rabinovich. Ehlementarnaya teoriya lezviya i metody proektirovaniya samozatachivayushchikhsya pochvorezhushchikh lezvij, Traktory i sel'khozmashiny, № 10, pp. 33-36, 1961.

7. A.N. Rozenbaum. Primenenie dvukhslojnogo prokata dlya pochvorezhushchikh samozatachivayushchikhsya detalej, Traktory $i$ 
Tamara Skoblo et al., International Journal of Emerging Trends in Engineering Research, 9(6), June 2021, 643 - 650

sel'khozmashiny, № 10, pp. 27-29, 1966.

8. S.A. Sidorov, D.A. Mironov, YU.S. Cench, and A.V. Mironova. Ocenka iznosostojkosti i resursa dvukhslojnykh uprochnennykh pochvorezhushchikh rabochikh organov $v$ razlichnykh pochvennykh usloviyakh, Inzhenernye tekhnologii i sistemy, T. 30, № 4, pp. 699-710, 2020. DOI $10.15507 / 2658-4123.030 .202004 .699-710$

9. A.A. Dudnikov, A.I. Belovod, A.G. Pasyuta, A.A. Kelemesh, and A.V. Gorbenko. Tekhnologicheskie sposoby povysheniya dolgovechnosti i resursa rabochikh organov pochvoobrabatyvayushchikh mashin, Mashinovedenie $i$ Mashinostroenie, Tekhnologicheskij audit $i$ rezervy proizvodstva, №5/1(25), pp. 4-7, 2015 DOI: $10.15587 / 2312-8372.2015 .48825$

10. S.A. Sidorov, D.A. Mironov, V.K. Khoroshenkov \& E.I. Khlusova. Surfacing methods for increasing the service life of rapidly wearing working tools of agricultural machines, Welding International, 30:10, pp. $\quad 808-812, \quad 2016 . \quad$ DOI:10.1080 / 09507116.2016.1148408

11. S. Strebkov, A. Slobodyuk, A. Bondarev, and A. Sakhnov. Strengthening of cultivator paws with electrospark doping, in Engineering for rural development, Jelgava, 2019, pp. 549-554.

12. V. Shakhov, S. Ivanovs, P. Uchkin, and Y. Ushakov. Studies in coatings for working bodies of deep-rippers recovered by plasma surfacing, in Engineering for rural development, Jelgava, 2019, pp. 44-49.

13. M.O. Vasilenko, and D. O. Buslaiev. Influence of the modes of application of the hardening coating on the parameters of the point hardening of the working bodies of the tillage machines, Scientific-theoretical journal of the National Academy of Agrarian Sciences of Ukraine. Bulletin of agrarian science, No. 7, pp. 44-48, 2015.

14. V. Mank, O. Tonkha, V. Galimova, S. Surovtsev, O. Menshov, O. Bukova, and I. Rogovskiy. Electrochemical investigation of cobalt absorbtion processes by soils of Ukraine, Visnyk of Taras Shevchenko National University of Kyiv-Geology, Vol. 3 (86), pp. 31-39, 2019.

15. I.L. Rogovskii, L.L. Titova, V.I. Trokhaniak, O.I. Haponenko, M.M. Ohiienko, and V.P. Kulik. Engineering management of tillage equipment with concave disk spring shanks, INMATEH, Agricultural Engineering, Vol. 60, No 1, pp. 45-52, 2020. DOI: 10.35633/INMATEH-60-05.

16. M.O. Vasylenko, and D.O. Buslayev. Matematychni modeli prohnozuvannya vahovoho i linijnoho znoshen" vid resursnyx pokaznykiv serijnyx i zmicnenyx kombinovanym metodom kul"tyvatornyx lap, Machinery \& Energetics. Journal of Rural
Production Research, Vol. 11, No 2, pp. 29-33, 2020. DOI: 10.31548/machenergy.2020.02.029-033

17. UA Patent No. 13760. Flyus dlya nanesennya pokryttya; publication 11.07.2016, Byul. No. 13 .

18. UA Patent No.130824. Sposib pidvyshhennya znosostijkosti strilchastoyi lapy kul"tyvatora; publication 26.12.2018, Byul. No. 24.

19. US Patent No.: 7,304,020 B1. Nano-particle metal treatment composition for creating a ceramic-metal layer; Date of Patent: Dec. 4, 2007.

20. T.S. Skoblo, O.Yu. Klochko, and E.L. Belkin. Structure of high-chromium cast iron, Steel in Translation, 42, №3, pp. 261-268, 2012 . http://doi.org/10.3103/S0967091212030151

21. T. S. Skoblo, O. YU. Klochko, E. L. Belkin, and A. I. Sidashenko. Novye podkhody $\mathbf{v}$ issledovanii neodnorodnosti geterogennykh struktur, Metallofizika $i$ novejshie tekhnologii, т.40, №2, pp. 255-280, 2018. DOI:10.15407/mfint.40.02.0255

22. N.A. Slezkin. Dinamicheskaya vyazkost' zhidkostiyu, Moskva: Gos. Izd-vo tekhniko-teoretich. lit., 1955, 520p.

23. M.N. Bulaeva, O.I. Vaganova, Zh.V. Smirnova, L.Yu. Shobonova, and E.A. Chelnokova. Study of the structure of metal materials using microanalysis, International Journal of Emerging Trends in Engineering Research, 8(7), pp. 3509-3512, 2020.

https://doi.org/10.30534/ijeter/2020/101872020

24. T.S. Skoblo, O.Yu. Klochko, O.I. Sidashenko, J.L. Belkin, A.K. Avtuxov, T.V. Mal"cev, Ye.S. Deryabkina, and N.M. Kolpachenko. Oznaky dehradaciyi karbidnyx faz u xromonikelevomu chavuni za temperatur ekspluataciyi prokatnyx valkiv, Fizyko-ximichna mexanika materialiv, №6, pp. 45-51, 2020.

25. T.S. Skoblo, O.YU. Klochko, and E.L. Belkin. Primenenie komp'yuternogo analiza metallograficheskikh izobrazhenij pri issledovanii struktury vysokokhromistogo chuguna, Zavodskaya laboratoriya, Diagnostika materialov, T. 78, №6, pp. 35-42, 2012.

26. T.S. Skoblo, O.YU. Klochko, A.I. Sidashenko, and E.L. Belkin. Teoreticheskie i ehksperimental'nye osnovy prognozirovaniya strukturoobrazovaniya, svojstv vysokouglerodnykh legirovannykh splavov: monografiya, Khar'kov: Disa plyus, 2019, 278 p.

27. T. Skoblo, I. Rybalko, A. Tihonov, and T. Maltsev Evaluation of the stress state of a cultivator blade in production and operation, Research in Agricultural Engineering, Vol. 66, Issue 2, pp. 60-65, 2020. https://doi.org/10.17221/8/2020-RAE 